\title{
Bactericidal Activity and Synergy Studies of Peptide AP-CECT7121 Against Multi-resistant Bacteria Isolated from Human and Animal Soft Tissue Infections
}

\author{
Gastón Delpech $^{1} \cdot$ Mariana Bistoletti $^{2} \cdot$ Mónica Ceci $^{1} \cdot$ Sabina Lissarrague ${ }^{1}$. \\ Sergio Sánchez Bruni ${ }^{2}$ • Mónica Sparo ${ }^{1}$ (i)
}

(C) Springer Science+Business Media New York 2017

\begin{abstract}
AP-CECT7121 is an antimicrobial peptide, produced by Enterococcus faecalis CECT7121, with bactericidal activity against Gram-positive bacteria. The aim of this study was to evaluate the bactericidal activity of AP-CECT7121, alone and with gentamicin, against multi-resistant bacteria isolated from human and animals with soft tissue infections. During the period 2014-2015, bacterial strains producing human and animal soft tissue infections were studied. Samples from patients attended at a general hospital and cattle from four dairies in the Province of Buenos Aires (Argentina) were included. Twenty-two methicillin-resistant Staphylococcus aureus (11, human blood samples; 11, cow milk) and five vancomycin-resistant Ent. faecium strains isolated from four mastitic dairy cows were tested. AP-CECT7121 (12 mg/L) potency was assessed by time-kill curves alone or with subinhibitory concentrations of gentamicin. All staphylococcal strains were susceptible to gentamicin; enterococci did not show high-level gentamicin resistance. Colony counts were carried out at $0,2,4,8$, and $24 \mathrm{~h}$ of incubation. APCECT7121 showed bactericidal activity against all the enterococcal strains. In addition, AP-CECT7121 had a bactericidal effect on most staphylococci (16/22). Early AP-CECT7121/ gentamicin synergy (4-8 h) for all staphylococci was detected. At $24 \mathrm{~h}$, synergy (19/22) and indifference (3/22) were observed. Synergy with gentamicin was detected for
\end{abstract}

Mónica Sparo

monicasparo@gmail.com

1 Microbiología Clínica, Medicina, Universidad Nacional del Centro de la Provincia de Buenos Aires, Av. Pringles 4375 (7400), Olavarría, Argentina

2 Centro de Investigación Veterinaria de Tandil (CONICET-UNCPBA), Campus Universitario (7000), Tandil, Argentina staphylococci. AP-CECT7121 constitutes an attractive candidate for its use as a natural therapeutic tool for the treatment of infections produced by multi-resistant Staph. aureus and vancomycin-resistant Ent. faecium isolated from humans and animals.

Keywords AP-CECT7121 - Bactericidal activity · Enterococcus faecium · Staphylococcus aureus · Skin and soft tissue

\section{Introduction}

Bovine mastitis is an intramammary infection caused by a wide spectrum of microorganisms. It has a significant relevance for milk industry with a negative impact on costs, quality, and volume of dairy production [1].

Gram-positive bacteria such as Staphylococcus aureus are among the most prevalent etiological agents of this infectious disease. However, Enterococcus faecium and Ent. faecalis are associated with environmental bovine mastitis due to inadequate hygiene practices [2].

Nowadays, antimicrobial multi-resistant bacteria are emerging and spreading globally, threatening the possibility to treat common infectious diseases. According to the Healthcare Infection Control Practices Advisory Committee from the Centers for Disease Control and Pevention (HICPAC-CDC), bacteria expressing resistance to more than one class of antimicrobial agents are defined as multi-resistant oganisms (https://www.cdc.gov/hicpac/mdro/mdro 2.html).

In human medicine, the use of antimicrobials exerts a high selective pressure upon prevalent pathogens, as methicillinresistant Staph. aureus (MRSA), which expresses resistance to beta-lactams. Selection of multi-resistant bacteria leads to the existence of few remaining therapeutic options [3]. 
Community-associated MRSA differ in certain aspects with healthcare associated multi-resistant staphylococci, such as the target population, clinical syndromes (e.g., severe sepsis, necrotizing fasciitis, and necrotizing pneumonia), susceptibility patterns (SCCmec cassettes), and infections in healthcare environment as well as in the community $[4,5]$.

Resistance to beta-lactams has also been detected in Staph. aureus isolated from farm animal, e.g., cattle, currently known as livestock-associated MRSA (LA-MRSA). Besides occupational contact, private farm visits or contact with persons who are directly exposed to livestock may also increase the risk for LA-MRSA acquisition [6].

For more than 20 years, vancomycin-resistant Ent. faecium have been acknowledged as etiological agents of human infectious diseases. However, the same variants of the vanA gene cluster (Tn1546) encoding vancomycin resistance can be detected in enterococci of both human and animal origin [7].

Gentamicin is widely used together with cell-wall active agents (beta-lactams, vancomycin) for the treatment of severe infectious diseases caused by vancomycin-resistant Ent. faecium VRE and MRSA [8, 9].

Soft tissue infections are an important morbidity factor among hospitalized patients and represent a therapeutic challenge for physicians. Selection of appropriate antimicrobials is one of the most important keys for a successful treatment. Gram-positive bacteria are the predominantly isolated organisms from patients with these severe infections [10].

Nowadays, the absence of new pharmacological options for the treatment of infectious diseases led to the search of new therapeutic strategies that can be a complement for conventional antimicrobials. One possibility is the antagonism mediated by bacterial proteins. Bacteriocins are antimicrobial peptides with bactericidal activity [11].

Peptide AP-CECT712 is an enterocin produced by the probiotic Ent. faecalis CECT7121, a non-hemolytic, gelatinase negative strain recovered from a natural corn silage in Tandil District, Argentina. Moreover, it does not show antimicrobial multiresistance (minimum inhibitory concentration $[\mathrm{MIC}]_{\text {vancomycin }} 0.12 \mu \mathrm{g} / \mathrm{mL}, \mathrm{MIC}_{\text {ampicillin }} 0.5 \mu \mathrm{g} / \mathrm{mL}$, $\mathrm{MIC}_{\text {gentamicin }}<500 \mu \mathrm{g} / \mathrm{mL}, \mathrm{MIC}_{\text {streptomycin }}<1000 \mu \mathrm{g} /$ $\mathrm{mL)}[12,13]$.

Physicochemical studies showed that AP-CECT7121 presents heat-stability $\left(1 \mathrm{~h}, 75^{\circ} \mathrm{C}\right)$. Also, it is sensitive to proteolytic enzymes, detergents, and chelants; in addition, it is stable against the activity of enzymes such as DNase, RNase, amilase, glucuronidase, and lipase. Furthermore, presents inhibitory activity among a wide range of $\mathrm{pH}$ values (4.0-8.0). AP-CECT7121 is a cationic hydrophobic peptide, with a low molecular weight (3000 Da) included in class II bacteriocins. The mechanism of action is mediated by formation of pores in bacterial membranes, followed by osmotic shock and cell lysis [13].
The aim of this study was to evaluate the bactericidal activity of AP-CECT7121 alone and with gentamicin against multi-resistant bacteria isolated from human and animal soft tissue infections.

\section{Materials and Methods}

\section{Bacterial Strains}

During the period of January 2014-December 2015, multiresistant bacterial strains producing human and animal soft tissue infections were included.

Methicillin-resistant Staph. aureus and vancomycinresistant Ent. faecium were recovered from mastitic dairy cows. Milk samples were obtained from $n: 4$ dairy farms (DF01-DF04), with a mean number of 700 dairy cows, located at the District of Tandil, Argentina.

Human MRSA were isolated from blood samples of patients with severe soft tissue infections attending at Ramón Santamarina Hospital's Emergency Room (Tandil, Argentina), under Medical prescription. One bacterial strain per patient was included.

\section{Phenotypic Characterization}

Phenotypic characterization of Ent. faecium and Staph. aureus were carried out according to Sparo et al. [12] and Winn et al. [14], respectively. VITEK 2® Compact automated system (bioMérieux, Buenos Aires, Argentina) was used for validation of phenotypic characterization.

\section{Antimicrobial Susceptbility Testing}

Preliminary antimicrobial susceptibility studies (disk diffusion) for staphylococcal and enterococcal isolates were done. Multi-resistant Staph. aureus (resistant to beta-lactams, erythromycin, and tetracycline) and Ent. faecium isolates (resistant to vancomycin, ampicillin, and tetracyciline) were selected.

MRSA ( $n$ : 11) and VRE ( $n: 5)$ from 16 different mastitic dairy cows were studied. MRSA were recovered from dairy farms DF01 (5/11), DF02 (1/11), DF03 (3/11), and DF04 $(2 / 11)$. VRE were isolated from animals at dairy farms DF02 (2/5), DF03 (2/5), and DF04 (1/5).

MIC was determined by the agar dilution method, according to the Clinical and Laboratory Standards Institute's recommendations, CLSI [15]. The following antimicrobials were tested: cefoxitin (MRSA), gentamicin (MRSA, VRE), vancomycin (VRE), and teicoplanin (VRE). Ent. faecalis ATCC 29212, Ent. faecalis ATCC 51299, and Staph. aureus ATCC 29213 were used for quality control. 


\section{Isolation of AP-CECT7121}

Isolation of AP-CECT7121 was carried out according to the protocol of Sparo et al. [16]. Probiotic strain Ent. faecalis CECT7121 (deposited at the Spanish Collection of Type Cultures, CECT, Burjasot, Valencia, Spain) was incubated in brain-heart infusión (BHI) broth (Laboratorio Britania, Buenos Aires, Argentina) at $35 \pm 2{ }^{\circ} \mathrm{C}$ for $18 \mathrm{~h}$. This culture was inoculated in $4 \mathrm{~L}$ of BHI broth and incubated at $35 \pm 2{ }^{\circ} \mathrm{C}$ for $9 \mathrm{~h}$. Then, it was centrifuged at $15,000 \mathrm{~g}, 4^{\circ} \mathrm{C}$, for $20 \mathrm{~min}$. Supernatant was adjusted to $\mathrm{pH}: 7.0$ and precipitated according to Dawson et al. [17]. After centrifugation at 20,000g, $4{ }^{\circ} \mathrm{C}$, for $20 \mathrm{~min}$, the pellet was re-suspended in $40 \mathrm{~mL}$ of phosphate buffer saline (PBS), pH: $7.0(50 \mathrm{mM})$.

AP-CECT7121 was isolated by physicochemical extraction employing Sep-Pak ${ }^{\mathrm{TM}} \mathrm{C} 18$ cartridges (Waters, Milford, MS, USA). Ent. faecalis extract $(5.0 \mathrm{~mL})$ was loaded into a cartridge, previously washed with acetonitrile in trifluoroacetic acid (TFA, $0.1 \%$ ), and it was eluted with acetonitrile $(60 \%)$-TFA $(0.1 \%)$. Eluate was concentrated to dryness using a vacuum centrifuge (ThermoSavant Instuments, Hollbrook, NY, USA). The obtained pellet was re-suspended in PBS $(250 \mu \mathrm{L})$.

Aliquotes $(20 \mu \mathrm{L})$ of the suspensión were injected in a reverse-phase HPLC system (Shimadzu, Kyoto, Japan) and separated in a Nucleosil C18 (5 $\mu \mathrm{m}$, Pharmacia, Uppsala, Sweden) column. Mobile phase: buffer A (TFA 0.1\%) and buffer B (acetonitrile 95\% in TFA 0.1\%). AP-CECT7121 was eluted using a linear gradient $(95 \% \mathrm{~A} / 5 \%$ B to $15 \%$ $\mathrm{A} / 85 \% \mathrm{~B}$ ), with a flow rate of $0.2 \mathrm{~mL} / \mathrm{min}$, controlling elution with a UV detector. Fractions were collected at regular time period. Then, the active fraction was evaporated to dryness and re-suspended in phosphate buffer $(50 \mathrm{mM}, \mathrm{pH}$ : 7.0). Biological activity of AP-CECT7121 was detected in the eluate fractions after $30 \mathrm{~min}$ of the sample injection, when it was ca. $40 \%$ of buffer B.

\section{Time-Kill Curves}

Efficacy of in vitro bactericidal activity of AP-CECT7121 alone or combined with gentamicin, for assessing a synergistic effect, was studied carrying out time-kill curves. Three timekill curves were done for each isolate.

Fresh cultured bacterial cells were washed, suspended, and diluted in PBS, $50 \mathrm{mM}$, pH: 7.0, for reaching a $10^{6} \mathrm{CFU}$ inoculum. Samples $(100 \mu \mathrm{L})$ of each bacterial suspension were obtained at $0,4,8$, and $24 \mathrm{~h}$ of incubation $\left(35 \pm 2{ }^{\circ} \mathrm{C}\right)$. Viable colony counts were performed in brain-heart infusión agar, after incubation at $35 \pm 2{ }^{\circ} \mathrm{C}$ for $24 \mathrm{~h}$. AP-CECT7121 concentration used $12 \mathrm{mg} / \mathrm{L}$. A viable cell count in the same experimental conditions, with PBS, was performed as quality control [16].
For assessing a synergistic effect, viable cell counts were carried out with AP-CECT7121 combined with sub-inhibitory concentrations of gentamicin (MIC/4) and with gentamicin alone.

Bactericidal effect was defined as a decrease in viable counts with AP-CET7121 alone $\left(\Delta \geq-3 \log _{10}\right)$. Sinergy: an increase in lethality $\geq 1 \log$ at $4-8 \mathrm{~h}$ (early synergy, $\Delta \geq-1$ $\log _{10}$ ) and $\geq-2 \log _{10}$ at $24 \mathrm{~h}$ of incubation (late synergy, $\Delta$ $\geq-2 \log _{10}$ ) for AP-CECT7121-gentamicin combination compared with AP-CECT7121 alone. When synergy was not achieved after $24 \mathrm{~h}$, it was considered as indifference between AP-CECT7121 and the antimicrobial [18].

\section{Ethical Aspects}

Milk samples from mastitic dairy cows were obtained with the cooperation of each dairy farm Veterinarian. For the obtention of human blood samples, briefings with patients or their relatives were performed. Ethical legislation (Helsinki's Declaration, Argentinian Bill for Personal Data Protection) was applied.

\section{Results}

\section{Bacterial Strains and Antimicrobial Resistance}

All the animal and human Staph. aureus isolates included in this study were resistant to cefoxitin (MIC $\geq 8 \mu \mathrm{g} / \mathrm{mL}$ ). Therefore, these staphylococi were characterized as human MRSA and livestock-associated MRSA. In addition, 100\% of MRSA isolates showed no resistance to gentamicin (MIC $\leq 4 \mu \mathrm{g} / \mathrm{mL}$ ).

Human MRSA ( $n: 11)$ were recovered from blood samples, from different patients at an Emergency Room, later admitted to the hospital. Severe soft tissue infections were acquired in the community; patients did not have previous records of MRSA colonization nor infection, no history of hospitalization, surgery, dialysis, or admission to a nursing home on the previous year; no permanent catheters or medical devices that passed through the skin. A wide age range among the patients was observed (30-60 years old). Isolates were recovered from female (6/11) and male (5/11) patients.

Ent. faecium isolated from mastitic dairy cows expressed vancomycin (MIC $\geq 32 \mu \mathrm{g} / \mathrm{mL}$ ) and teicoplanin (MIC $\geq 32 \mu \mathrm{g} /$ $\mathrm{mL}$ ) resistance. This pattern was compatible with a glycopeptide-resistant VanA phenotype, and, hence, enterococci were characterized as VRE. High-level gentamicin resistance was not detected (MIC $<500 \mu \mathrm{g} / \mathrm{mL}$ ).

Bactericidal activity of AP-CECT7121 and synergy with gentamicin in MRSA isolated from mastitic cows.

AP-CECT7121 was bactericidal against 7/11 of the bovine methicillin-resistant staphylococci $\left(-3.7\right.$ to $-5.0 \log _{10} \mathrm{CFU} /$ 
$\mathrm{mL}$ ). Therefore, a $63.6 \%$ killing efficacy frequency was observed (Table 1).

Early synergy, at $4-8 \mathrm{~h}$, between APCECT7121 and gentamicin was detected in all the assayed mastitic staphylococci $\left(-1.0\right.$ to $\left.-1.6 \log _{10} \mathrm{CFU} / \mathrm{mL}\right)$. At $24 \mathrm{~h}$, in $8 / 11$ isolates
(72.7\%), synergy was observed ( -2.3 to $-5.0 \log _{10} \mathrm{CFU} /$ $\mathrm{mL}$ ), while indifference $3 / 11(27.3 \%)$ MRSA showed indifference $\left(-1.1\right.$ to $\left.-1.2 \log _{10} \mathrm{CFU} / \mathrm{mL}\right)$.

Bactericidal activity of AP-CECT7121 and synergy with gentamicin in VRE isolated from mastitic cows.

Table 1 Variation of cell counts $\left(\Delta \log _{10} \mathrm{CFU} / \mathrm{mL}\right)$ after AP-CECT7121 sinergy experiments with gentamicin in methicillin-resistant Staphylococcus aureus from mastitic cows

\begin{tabular}{|c|c|c|c|c|c|}
\hline Strain $^{a}$ & Time (h) & $\begin{array}{l}\text { Non } \text { ATM }^{\mathrm{b}} \\
\left(\Delta \log _{10} \mathrm{CFU} / \mathrm{mL}\right)^{\mathrm{c}}\end{array}$ & $\begin{array}{l}\text { AP-CECT7121 } \\
\left(\Delta \log _{10} \mathrm{CFU} / \mathrm{mL}\right)\end{array}$ & $\begin{array}{l}\mathrm{GEN}^{\mathrm{c}} \\
\left(\Delta \log _{10} \mathrm{CFU} / \mathrm{mL}\right)\end{array}$ & $\begin{array}{l}\text { AP-CECT7121 + GEN } \\
\left(\Delta \log _{10} \mathrm{CFU} / \mathrm{mL}\right)^{\mathrm{c}}\end{array}$ \\
\hline \multirow[t]{4}{*}{ DF01-120 } & 0 & 0 & 0 & 0 & 0 \\
\hline & 4 & 1.6 & -1.9 & 1.4 & -3.1 \\
\hline & 8 & 1.9 & -3.1 & 1.8 & -4.1 \\
\hline & 24 & 2.1 & -5.0 & 2.1 & $\mathrm{ND}^{\mathrm{d}}$ \\
\hline \multirow[t]{4}{*}{ DF02-138 } & 0 & 0 & 0 & 0 & 0 \\
\hline & 4 & 1.4 & -1.9 & 1.6 & -2.9 \\
\hline & 8 & 1.9 & -3.0 & 2.2 & -3.2 \\
\hline & 24 & 2.2 & -3.7 & 2.3 & ND \\
\hline \multirow[t]{4}{*}{ DF01-142 } & 0 & 0 & 0 & 0 & 0 \\
\hline & 4 & 1.3 & -2.0 & 1.7 & -3.2 \\
\hline & 8 & 1.9 & -3.2 & 2.0 & -3.4 \\
\hline & 24 & 2.1 & -4.4 & 2.2 & ND \\
\hline \multirow[t]{4}{*}{ DF04-145 } & 0 & 0 & 0 & 0 & 0 \\
\hline & 4 & 1.3 & -1.9 & 1.7 & -3.2 \\
\hline & 8 & 1.7 & -3.1 & 2.0 & -3.4 \\
\hline & 24 & 2.1 & -3.9 & 2.1 & ND \\
\hline \multirow[t]{4}{*}{ DF04-153 } & 0 & 0 & 0 & 0 & 0 \\
\hline & 4 & 1.2 & -2.0 & 1.4 & -3.0 \\
\hline & 8 & 1.7 & -3.1 & 1.8 & -4.1 \\
\hline & 24 & 2.3 & -4.3 & 2.0 & ND \\
\hline \multirow[t]{4}{*}{ DF03-157 } & 0 & 0 & 0 & 0 & 0 \\
\hline & 4 & 1.4 & -1.7 & 1.5 & -2.8 \\
\hline & 8 & 1.9 & -2.6 & 2.0 & -3.7 \\
\hline & 24 & 2.1 & -4.1 & 2.2 & ND \\
\hline \multirow[t]{4}{*}{ DF03-163 } & 0 & 0 & 0 & 0 & 0 \\
\hline & 4 & 1.7 & -1.5 & 1.7 & -2.6 \\
\hline & 8 & 1.9 & -2.7 & 2.0 & -3.8 \\
\hline & 24 & 2.0 & -4.1 & 2.0 & ND \\
\hline \multirow[t]{4}{*}{ DF01-167 } & 0 & 0 & 0 & 0 & 0 \\
\hline & 4 & 1.6 & -0.8 & 1.7 & -1.8 \\
\hline & 8 & 2.0 & -1.3 & 2.1 & -2.6 \\
\hline & 24 & 2.2 & -2.4 & 2.2 & ND \\
\hline \multirow[t]{4}{*}{ DF01-172 } & 0 & 0 & 0 & 0 & 0 \\
\hline & 4 & 1.6 & -0.5 & 1.4 & -2.1 \\
\hline & 8 & 2.0 & -1.3 & 1.8 & -2.5 \\
\hline & 24 & 2.3 & -2.6 & 2.0 & -3.7 \\
\hline \multirow[t]{4}{*}{ DF03-178 } & 0 & 0 & 0 & 0 & 0 \\
\hline & 4 & 1.7 & -1.1 & 1.3 & -2.2 \\
\hline & 8 & 2.1 & -1.9 & 1.9 & -2.9 \\
\hline & 24 & 2.2 & -2.5 & 2.2 & -3.6 \\
\hline \multirow[t]{4}{*}{ DF01-179 } & 0 & 0 & 0 & 0 & 0 \\
\hline & 4 & 1.4 & -0.9 & 1.4 & -2.1 \\
\hline & 8 & 2.0 & -1.6 & 2.0 & -2.7 \\
\hline & 24 & 2.1 & -2.3 & 2.0 & -3.5 \\
\hline
\end{tabular}

Italicized item states the decrease of CFU was higher than 3log, defined as bactericidal effect of AP-CECT7121

${ }^{a}$ Strain code: establishment + identification number

${ }^{\mathrm{b}}$ Antimicrobial

${ }^{\mathrm{c}}$ Gentamicin

${ }^{\mathrm{d}}$ Not detected 
Bactericidal activity of AP.CECT7121 against VRE was detected (Table 2). Higher decrease in enterococcal counts were observed, when there were compared with staphylococcal counts ( -4.3 to $\left.-6.2 \log _{10} \mathrm{CFU} / \mathrm{mL}\right)$.

However, the activity of AP-CECT7121 with gentamicin was slightly enhanced against enterococci. In $4 / 5$ isolates, there was not proved early synergy $(-0.2$ to $\left.-0.9 \log _{10} \mathrm{CFU} / \mathrm{mL}\right)$. Nevertheless, early synergy was observed in $1 / 5 \operatorname{VRE}\left(-1.3 \log _{10} \mathrm{CFU} / \mathrm{mL}\right)$ at $4-8 \mathrm{~h}$, and synergy was detected in $2 / 5$ VRE at $24 \mathrm{~h}$ $\left(-4.3 \log _{10} \mathrm{CFU} / \mathrm{mL}\right)$.

Bactericidal activity of AP-CECT7121 and synergy with gentamicin in human community-origin MRSA.

Bactericidal activity of AP-CECT7121 was observed in 9/11 (81.8\%) multi-resistant community-origin MRSA $\left(-3.1\right.$ to $\left.-3.8 \log _{10} \mathrm{UFC} / \mathrm{mL}\right)$ recovered from human patients (Table 3).

In all the staphylococcal isolates, early synergy was detected, at $4-8 \mathrm{~h}\left(-1.0\right.$ to $\left.-1.3 \log _{10} \mathrm{UFC} / \mathrm{mL}\right)$. However, indifference was observed in $100 \%$ of the human MRSA $\left(\leq-1.1 \log _{10} \mathrm{UFC} / \mathrm{mL}\right)$.

\section{Discussion}

Bactericidal activity of the antimicrobial peptide APCECT7121 and a synergistic effect with gentamicin were assayed against human and animal multi-resistant bacteria. MRSA and VRE strains were selected based on their epidemiological relevance.

Isolation of VRE from mastitic cows represents a relevant concern for human health. Previous studies showed the horizontal transfer of van genes between enterococci from different origin, as well as between vancomycin-resistant Ent. faecium and Staph. aureus [19, 20]. Previously, in the same studied region, VRE were recovered from artisanal cow cheese, strengthening the possibility of antimicrobial resistance transfer to humans through the food chain [21].

Emergence of community-associated MRSA has been linked with an increase in beta-lactam resistant staphylococci. A meta-analysis showed high pooled prevalence rates of community-associated MRSA infections in Asia (23.1\%), Europe (37.4\%), and North America (47.4\%). These findings highlighted the epidemiological relevance of community-

Table 2 Variation of cell counts $\left(\Delta \log _{10} \mathrm{CFU} / \mathrm{mL}\right)$ after AP-CECT7121 sinergy experiments with gentamicin in vancomycin-resistant Enterococcus faecium from mastitic cows

\begin{tabular}{|c|c|c|c|c|c|}
\hline Strain $^{\mathrm{a}}$ & Time (h) & $\begin{array}{l}\text { Non } \mathrm{ATM}^{\mathrm{b}} \\
\left(\Delta \log _{10} \mathrm{CFU} / \mathrm{mL}\right)\end{array}$ & $\begin{array}{l}\text { AP-CECT7121 } \\
\left(\Delta \log _{10} \mathrm{CFU} / \mathrm{mL}\right)\end{array}$ & $\begin{array}{l}\mathrm{GEN}^{\mathrm{c}} \\
\left(\Delta \log _{10} \mathrm{CFU} / \mathrm{mL}\right)\end{array}$ & $\begin{array}{l}\mathrm{AP}-\mathrm{CECT} 7121+\mathrm{GEN}( \\
\left.\Delta \log _{10} \mathrm{CFU} / \mathrm{mL}\right)\end{array}$ \\
\hline \multirow[t]{4}{*}{ DF02-043 } & 0 & 0 & 0 & 0 & 0 \\
\hline & 4 & 1.6 & -1.8 & 1.5 & -2.7 \\
\hline & 8 & 2.1 & -3.7 & 2.3 & -3.5 \\
\hline & 24 & 2.3 & -4.3 & 2.5 & $\mathrm{ND}^{\mathrm{d}}$ \\
\hline \multirow[t]{4}{*}{ DF04-056 } & 0 & 0 & 0 & 0 & 0 \\
\hline & 4 & 1.5 & -1.9 & 1.5 & -2.6 \\
\hline & 8 & 2.2 & -3.3 & 2.1 & -4.1 \\
\hline & 24 & 2.5 & -4.3 & 2.3 & ND \\
\hline \multirow[t]{4}{*}{ DF02-065 } & 0 & 0 & 0 & 0 & 0 \\
\hline & 4 & 1.7 & -2.2 & 1.7 & -2.8 \\
\hline & 8 & 2.2 & -3.3 & 2.2 & -4.1 \\
\hline & 24 & 2.5 & $N D$ & 2.4 & ND \\
\hline \multirow[t]{4}{*}{ DF03-072 } & 0 & 0 & 0 & 0 & 0 \\
\hline & 4 & 1.6 & -2.1 & 1.3 & -2.8 \\
\hline & 8 & 2.0 & -3.2 & 1.9 & -3.6 \\
\hline & 24 & 2.3 & $N D$ & 2.3 & ND \\
\hline \multirow[t]{4}{*}{ DF03-078 } & 0 & 0 & 0 & 0 & 0 \\
\hline & 4 & 1.5 & -2.3 & 1.4 & -3.6 \\
\hline & 8 & 1.9 & -4.2 & 2.0 & -4.2 \\
\hline & 24 & 2.1 & $N D$ & 2.1 & ND \\
\hline
\end{tabular}

Italicized item states the decrease of CFU was higher than 3log, defined as bactericidal effect of AP-CECT7121

${ }^{\text {a }}$ Strain code: establishment + identification number

${ }^{\mathrm{b}}$ Antimicrobial

${ }^{\mathrm{c}}$ Gentamicin

${ }^{\mathrm{d}}$ Not detected 
Table 3 Variation of cell counts $\left(\Delta \log _{10} \mathrm{CFU} / \mathrm{mL}\right)$ after APCECT7121 sinergy experiments with gentamicin in methicillinresistant Staphylococcus aureus from human skin and soft-tissue human infections

\begin{tabular}{|c|c|c|c|c|c|}
\hline Strain $^{\mathrm{a}}$ & Time (h) & $\begin{array}{l}\text { Non } \mathrm{ATM}^{\mathrm{b}} \\
\left(\Delta \log _{10} \mathrm{CFU} / \mathrm{mL}\right)\end{array}$ & $\begin{array}{l}\text { AP-CECT7121 } \\
\left(\Delta \log _{10} \mathrm{CFU} / \mathrm{mL}\right)\end{array}$ & $\begin{array}{l}\mathrm{GEN}^{\mathrm{c}} \\
\left(\Delta \log _{10} \mathrm{CFU} / \mathrm{mL}\right)\end{array}$ & $\begin{array}{l}\text { APCECT+ GEN } \\
\left(\Delta \log _{10} \mathrm{CFU} / \mathrm{mL}\right)\end{array}$ \\
\hline \multirow[t]{4}{*}{ HS-224 } & 0 & 0 & 0 & 0 & 0 \\
\hline & 4 & 1.8 & -0.7 & -0.9 & -0.9 \\
\hline & 8 & 2.7 & -1.4 & -1.5 & -2.7 \\
\hline & 24 & 3.9 & -3.8 & -2.8 & -3.7 \\
\hline \multirow[t]{4}{*}{ HS-228 } & 0 & 0 & 0 & 0 & 0 \\
\hline & 4 & 1.6 & -0.8 & -0.7 & -0.7 \\
\hline & 8 & 2.5 & -1.7 & -1.7 & -2.7 \\
\hline & 24 & 3.8 & -3.8 & -2.9 & -3.9 \\
\hline \multirow[t]{4}{*}{ HS-232 } & 0 & 0 & 0 & 0 & 0 \\
\hline & 4 & 1.3 & -0.8 & -0.8 & -0.6 \\
\hline & 8 & 2.6 & -1.6 & -1.7 & -2.8 \\
\hline & 24 & 3.7 & -3.5 & -3.0 & -3.6 \\
\hline \multirow[t]{4}{*}{ HS-235 } & 0 & 0 & 0 & 0 & 0 \\
\hline & 4 & 1.8 & -0.7 & -0.7 & -0.9 \\
\hline & 8 & 2.4 & -1.1 & -1.5 & -2.2 \\
\hline & 24 & 3.5 & -3.2 & -2.7 & -3.2 \\
\hline \multirow[t]{4}{*}{ HS-242 } & 0 & 0 & 0 & 0 & 0 \\
\hline & 4 & 1.6 & -0.5 & -0.9 & -0.9 \\
\hline & 8 & 2.1 & -1.2 & -1.5 & -2.2 \\
\hline & 24 & 3.4 & -2.6 & -2.7 & -2.5 \\
\hline \multirow[t]{4}{*}{ HS-243 } & 0 & 0 & 0 & 0 & 0 \\
\hline & 4 & 1.4 & -0.8 & -0.4 & -0.7 \\
\hline & 8 & 2.0 & -1.6 & -1.4 & -2.8 \\
\hline & 24 & 3.5 & -3.3 & -2.9 & -3.3 \\
\hline \multirow[t]{4}{*}{ HS-247 } & 0 & 0 & 0 & 0 & 0 \\
\hline & 4 & 1.5 & -0.7 & -0.7 & -0.8 \\
\hline & 8 & 2.3 & -1.5 & -1.5 & -2.7 \\
\hline & 24 & 3.2 & -3.1 & -3.0 & -3.2 \\
\hline \multirow[t]{4}{*}{ HS-253 } & 0 & 0 & 0 & 0 & 0 \\
\hline & 4 & 1.3 & -0.9 & -0.5 & -0.6 \\
\hline & 8 & 2.5 & -1.4 & -1.2 & -2.5 \\
\hline & 24 & 3.8 & -3.6 & -2.8 & -3.5 \\
\hline \multirow{4}{*}{ HS-256 } & 0 & 0 & 0 & 0 & 0 \\
\hline & 4 & 1.6 & -0.4 & -0.5 & -0.4 \\
\hline & 8 & 2.7 & -1.1 & -1.0 & -2.2 \\
\hline & 24 & 3.8 & -2.4 & -2.2 & -2.3 \\
\hline \multirow{4}{*}{ HS-257 } & 0 & 0 & 0 & 0 & 0 \\
\hline & 4 & 1.1 & -0.7 & -0.6 & -0.8 \\
\hline & 8 & 1.7 & -1.4 & -1.0 & -2.6 \\
\hline & 24 & 3.4 & -3.1 & -2.7 & -3.2 \\
\hline \multirow{4}{*}{ HS-262 } & 0 & 0 & 0 & 0 & 0 \\
\hline & 4 & 1.3 & -1.0 & -0.6 & -0.8 \\
\hline & 8 & 2.5 & -1.7 & -1.1 & -2.7 \\
\hline & 24 & 3.6 & -3.4 & -3.0 & -3.5 \\
\hline
\end{tabular}

Italicized item states the decrease of CFU was higher than $3 \log$, defined as bactericidal effect of AP-CECT7121

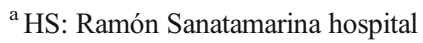

${ }^{\mathrm{b}}$ Antimicrobial

${ }^{\mathrm{c}}$ Gentamicin associated MRSA as an etiological agent of human invasive infectious diseases [22].

In this study, the effectiveness of enterocin AP-CECT7121 as antimicrobial peptide on human and animal strains was investigated. Other authors focused on bacteriocins synthesized by other genera such as Bacillus spp., Staphylococcus spp., Streptococcus spp., and Lactococcus spp. [23].

So far, research for development of bacteriocins for therapeutic purposes has focused on antimicrobial peptides such as nisin, lacticin, and lysostaphin. Interestingly, is needed to highlight that AP-CECT7121 is produced by a probiotic strain, with proved no toxic or nocive effects $[13,24,25]$.
AP-CECT7121 showed bactericidal activity against MRSA isolated from mastitic cows (63.6\%). A similar inhibition activity (60\%) against MRSA strains was observed for a fusion peptide, pheromonicin. However, nisin therapy had a lower success rate $(54.5 \%)$, when assayed against mastitic Staph. aureus [24, 25]. Furthermore, the inhibitory activity of seven staphylococcal bacteriocins was tested against 165 Staph. aureus isolated from mastitic cows in Brazil and Argentina. Inhibitory activity of staphylococcins was detected against Brazilian (091.5\%) and Argentinian (0-100\%) Staph. aureus, a potential pathogenic bacterial species [26]. 
AP-CECT7121 showed a bactericidal effect against mastitic MRSA. In a previous study, bactericidal activity of three different bacteriocins against planktonic MRSA cells was assessed. Nisin A and lacticin Q had a bactericidal mode of action, in less than $24 \mathrm{~h}$ after the administration of the bacteriocins [27].

Bovine VRE isolates recovered from mastitic cows were killed by AP-CECT7121, with a viable cells decrease over $4.0 \log _{10} \mathrm{UFC} / \mathrm{mL}$. Similar results were reported for nisin with clinical enterococci. After $4 \mathrm{~h}$ of exposure to nisin, all the VRE isolates showed a $10^{4}$ fold loss of viability [28]. However, pumilicin 4 showed a mild inhibition effect against vancomycin-resistant enterococci. After $6 \mathrm{~h}$ of incubation, viable cell counts decreased ca. $2.0 \log _{10} \mathrm{UFC} / \mathrm{mL}$ and were over $7.0 \log _{10} \mathrm{UFC} / \mathrm{mL}$ after $24 \mathrm{~h}$ [29].

In vitro efficacy of AP-CECT7121 was assayed against human multi-resistant Staph. aureus. Bactericidal activity of the enterocin was detected in $81.8 \%$ of MRSA isolates. Pumilicin 4 showed a strong inhibition effect and a significant decrease in MRSA viability. Nevertheless, a faster bactericidal effect was observed for nisin against MRSA isolates, since a $10^{4}$ fold decrease was observed after $6 \mathrm{~h}[28,29]$.

The existence of a synergistic effect between APCECT7121 and gentamicin was investigated. Early synergy with AP-CECT7121 was observed for all the bovine and human MRSA, while late synergy was detected for bovine strains. Recently, two enterocins produced by Ent. faecalis, alone and combined with kanamycin, were assayed against a MRSA strain recovered from a human patient. When early and late synergistic effects were studied, enterocins altogether with kanamycin exerted those effects [30].

In a cow VRE strain, early synergy AP-CECT71/gentamicin was detected. In a previous study, it was investigated the bactericidal activity of three bacteriocins alone and in combination. When two bacteriocins were assayed together, a more effective bactericidal effect was observed against enterococci. A combination of all the bacteriocins was the most effective against VRE [31].

Approximately 7 to $10 \%$ of hospitalized patients are affected by skin and soft tissue infections, such as necrotizing fasciitis. Depending on the severity of the infection, the affected area may become dysfunctional $[32,33]$.

Traditionally, staphylococcal infections were treated with commonly used antimicrobials, but emergence of drugresistant bacteria is nowadays a major therapeutic concern. Community MRSA can cause severe or fatal diseases, and antimicrobial therapy requires second-line drugs or vancomycin. There are major issues with the utilization of vancomycin, including problems with prolonged bacteremia during therapy, high rates of clinical failure, and nephrotoxicity [34].

AP-CECT7121 showed homogenous bactericidal activity against most human MRSA isolates. However, there is scarce available information about the effectiveness of bacteriocins for the treatment of skin and soft tissue infections. Other authors found that although nisin seemed to be an effective option for the treatment of human mastitis, reductions in the staphylococcal counts of nisin-treated strains were under the limit for being considered as a bactericidal effect [35]. In another study, activity of nisin and lacticin 3147, against antimicrobial-resistant human staphylococci and enterococci, was investigated. Unlike AP-CECT7121, nisin was more effective against MRSA isolates, while lacticin 3147 showed a greater potency against human VRE [36].

In conclusión, AP-CECT7121 showed bactericidal activity alone against glycopeptide-resistant enterococci and methicillin-resistant staphylococci recovered from mastitic dairy cows and human patients with invasive soft tissue infections. Synergy with gentamicin was detected against bovine staphylococci, while indifference was observed for human S. aureus. AP-CECT7121 constitutes an attractive candidate for its use as a natural therapeutic tool for the treatment of bovine mastitis produced by animal multi-resistant bacteria, such as Staph.aureus and vancomycin-resistant Ent. faecium as well as for infectious diseases caused by MRSA.

\section{Compliance with Ethical Standards}

Conflict of Interest The authors declare that they have no conflict of interest.

Funding This study was funded by the Consejo Interuniveristario Nacional (PDTS CIN-CONICET 2014 \# 85), Buenos Aires, Argentina.

\section{References}

1. Pyörälä S (2009) Treatment of mastitis during lactation. Ir Vet J 62: 40-44

2. Contreras GA, Rodríguez JM (2011) Mastitis: comparative etiology and epidemiology. J Mammary Gland Biol Neoplasia 16:339-356

3. Canton R, Horcajada JP, Oliver A, Ruiz Garbajosa P, Vila J (2013) Inappropiate use of antibiotics in hospitals: the complex relationship between antibiotic use and antimicrobial resistance. Enferm Infecc Microbiol Clin 31:3-11

4. Lee TC, Carrick MM, Scott BG, Hodges JC, Pham HQ (2007) Incidence and clinical characteristics of methicillin-resistant Staphylococcus aureus necrotizing fasciitis in a large urban hospital. Am J Surg 194:809-812

5. David MZ, Daum RS (2010) Community-associated methicillinresistant Staphylococcus aureus: epidemiology and clinical consequences of an emerging epidemic. Clin Microbiol Rev 23:616-687

6. Becker K, Ballhausen B, Kahl BC, Köck R (2017) The clinical impact of livestock-associated methicillin-resistant Staphylococcus aureus of the clonal complex 398 for humans. Vet Microbiol 200:33-38

7. Hammerum AM (2012) Enterococci of animal origin and their significance for public health. Clin Microbiol Infect 18:619-625

8. Chambers HF (1997) Methicilin resistance in staphylococci: molecular and biochemical basis and clinical implications. Clin Microbiol Rev 10:781-791

9. Cercenado E (2011) Enterococcus: phenotype and genotype resistence and epidemiology in Spain. Enferm Infecc Microbiol Clin 29:59-65 
10. Ray GT, Suaya JA, Baxter R (2013) Incidence, microbiology, and patient characteristics of skin and soft-tissue infections in a U.S. population: a retrospective population-based study. BMC Infect Dis 13:252

11. Acuña L, Morero RD, Bellomio A (2011) Development of widespectrum hybrid bacteriocins for food biopreservation. Food Bioprocess Technol 4:1029-1049

12. Sparo M, Nuñez GG, Castro M, Calcagno ML, García Allende MA, Ceci M, Najle R, Manghi M (2008) Characteristics of an environmental strain, Enterococcus faecalis CECT7121 and its effects as additive on craft dry-fermented sausages. Food Microbiol 25:607-615

13. Sparo M (2006) Investigation of bacteriocins from lactic acid bacteria in Tandil District. Ph.D. thesis. University of Buenos Aires, Argentina. In Spanish.

14. Winn WC, Allen SD, Janda WM, Koneman EW, Procop GW, Schreckenberger PC, Woods GL (2008). Koneman. Diagnóstico microbiológico. $6^{\mathrm{a}}$ ed. Editorial Médica Panamericana, Buenos Aires

15. Clinical and Laboratory Standards Institute (2016) Performance standards for antimicrobial susceptibility testing, 26th informational supplement. M100-S26. CLSI, Wayne, PA

16. Sparo MD, Jones DG, Sánchez Bruni SF (2009) Assessment of the in vitro efficacy of the novel antimicrobial peptide CECT7121 against human Gram-positive bacteria from serious infections refractory to treatment. Chemotherapy 55:270-277

17. Dawson RMC, Elliot DC, Elliot WH, Jones KM (1969) Data for biochemical research, 2nd edn. Oxford University Press, Oxford

18. Krapp C, Moody JA (1992) Timed kill assay for determining synergy. In: Isenberg HD ed. ASM Manual of Clinical Microbiology. ASM Press, Washington DC

19. Lester CH, Frimodt-Møller N, Lund Sorensen T, Monnet DL, Hammerum AM (2006) In vivo transfer of the vanA resistance gene from an Enterococcus faecium isolate of animal origin to an E. faecium isolate of human origin in the intestine of human volunteers. Antimicrob Agents Chemother 50:596-599

20. de Niederhäusern S, Bondi M, Messi P, Iseppi R, Sabia C, Manicardi G, Anacarso I (2011) Vancomycin resistance transferability from VanA enterococci to Staphylococcus aureus. Curr Microbiol 62:1363-1367

21. Delpech G, Pourcel G, Schell C, de Luca M, Basualdo J, Bernstein J, Grenovero S, Sparo M (2012) Antimicrobial resistance profiles of Enterococcus faecalis and Enterococcus faecium isolated from artisanal food of animal origin in Argentina. Foodborne Pathog Dis 9: 939-944

22. Li S, Li J, Qiao Y, Ning X, Zeng T, Shen X (2014) Prevalence and invasiveness of community-acquired methicillin-resistant Staphylococcus aureus: a meta-analysis. Indian J Pathol Microbiol 57:418-422
23. Hammami R, Fernandez B, Lacroix C, Fliss I (2013) Anti-infective properties of bacteriocins: an update. Cell Mol Life Sci 70:2947-2967

24. Cao LT, Wu JQ, Xie F, Hu SH, Mo Y (2007) Efficacy of nisin in treatment of clinical mastitis in lactating dairy cows. J Dairy Sci 90: 3980-3985

25. Hassan M, Kjos M, Nes IF, Diep DB, Loftipour F (2012) Natural antimicrobial peptides from bacteria: characteristics and potential applications to fight against antibiotic resistance. J Appl Microbiol 113:723-736

26. Varella Coelho ML, Santos Nascmento JD, Fagundes PC, Madureira DJ, Oliveira SS, Vasconcelos de Paiva Brito MA, Freire Bastos M (2007) Activity of staphylococcal bacteriocins against Staphylococcus aureus and Streptococcus agalactiae involved in bovine mastitis. Res Microbiol 158:625-630

27. Okuda KI, Zendo T, Sugimoto S, Iwase T, Tajima A, Yamada S, Sonomoto K, Mizunoe Y (2013) Effects of bacteriocins on methicillin-resistant Staphylococcus aureus biofilm. Antimicrob Agents Chemother 57:5572-5579

28. Severina E, Severin A, Tomasz A (1998) Antibacterial efficacy of nisin against multidrug-resistant Grampositive pathogens. J Antimicorb Chemother 41:341-347

29. Aumpad R, Na-Bangchang K (2007) Pumilicin 4, a novel bacteriocin with anti-MRSA and anti-VRE activity produced by newly isolated bacteria Bacillus pumilus strain WAPB4. Curr Microbiol 55:308-313

30. Al Atya AK, Belguesmia Y, Chataigne G, Ravallec R, Vachée A, Szunerits S, Boukherroub R, Drider D (2016) Anti-MRSA activities of enterocins DD28 and DD93 and evidences on their role in the inhibition of biofilm formation. Front Microbiol 7:817

31. Kaur G, Singh TP, Malik RK, Bhardwaj A, De S (2014) Antibacterial efficacy of nisin, pediocin 34 and enterocin FH99 against L. monocytogenes, E. faecium and E. faecalis and bacteriocin cross resistance and antibiotic susceptibility of their bacteriocin resistant variants. J Food Sci Technol 51:233-244

32. Swartz MN (2004) Clinical practice. Cellulitis. N Engl J Med 350: 904-912

33. Ki V, Rotstein C (2008) Bacterial skin and soft tissue infections in adults: a review of their epidemiology, pathogenesis, diagnosis, treatment and site of care. Can J Infect Dis Med Microbiol 19: 173-184

34. Dombrowski JC, Winston LG (2008) Clinical failures of appropriately-treated methicillin-resistant Staphylococcus aureus infections. J Inf Secur 57:110-115

35. Fernández L, Delgado S, Herrera H, Maldonado A, Rodríguez JM (2008) The bacteriocin Nisin, an effective agent for the treatment of staphylococcal mastitis during lactation. J Hum Lact 24:311-316

36. Piper C, Draper LA, Coter PD, Ross RP, Hill C (2009) A comparison of the activities of lacticin 3147 and nisin against drug-resistant Staphylococcus aureus and Enterococcus species. J Antimicrob Chemother 64:546-551 